\title{
Phylogenetic characterisation of bacterial assemblages and the role of sulphur-cycle bacteria in an Arenicola marina bioturbated mesocosm
}

\author{
Elizabeth J. Ashforth ${ }^{1, *}$, Peter J. W. Olive ${ }^{2}$, Alan C. Ward ${ }^{1}$ \\ ${ }^{1}$ Microbial Resources Laboratory, School of Biology and ${ }^{2}$ School of Marine Science and Technology, Newcastle University, \\ Newcastle upon Tyne NE1 7RU, UK
}

\begin{abstract}
A culture-independent analysis of the bacterial assemblages in the sediments of a lugworm Arenicola marina L. bioturbated mesocosm was carried out using a molecular RNA-gene based approach. Clone libraries were constructed for 4 spatial locations in the mesocosm: deep yeast layer (DYL), mid sand (MS), new casts (NC) and old casts (OC) after $29 \mathrm{~d}$ of bioturbation. In total, 495 clones were analysed and grouped into 159 unique phylotypes. All libraries were dominated by Epsilonproteobacteria, with Alpha-, Delta- and Gammaproteobacteria, Verrucomicrobia and members of the Cytophaga-Flavobacteria-Bacteroides group also prevalent. Phyologenetic comparison of the sites with respect to evolutionary distance showed that the libraries fell into 2 groups: (1) DYL and MS and (2) NC and OC. There were significant differences in species composition between but not within the 2 groupings. Bacteria involved with sulphur cycling are most likely to be affected by lugworm bioturbation. An Epsilonproteobacterium phylotype with $>95 \% 16$ S similarity to Sulfurimonas denitrificans was abundant in the DYL sand layer but was not present in the egested sand (NC, OC). Promotion of the growth of sulphide-oxidising bacteria and their subsequent digestion would be consistent with the 'gardening' hypothesis and suggests that chemoautotrophic processes in shallow-water anaerobic sediments may be enhanced by the activities of the lugworm.
\end{abstract}

KEY WORDS: Arenicola marina - Mesocosm - Phylogeny · Microbial diversity · 16S rRNA · Sulphur cycling

Resale or republication not permitted without written consent of the publisher

\section{INTRODUCTION}

Burrowing invertebrates have a dynamic effect on the microbial flora associated with marine sediments (Aller 2001, Mermillod-Blondin \& Rosenberg 2006) and bacterial biomass is greater in burrowed than non-burrowed sediment (Alongi 1985, Steward et al. 1996, Phillips \& Lovell 1999, Papaspyrou et al. 2006).

Lugworms (Polychaeta, Arenicolidae) are a well known example of burrowing invertebrates in intertidal sand. Arenicola marina, characterised as a 'gallery diffuser' (Gérino et al. 2004), is often the dominant macrofaunal species in sandy intertidal marine sediments (Volkenborn et al. 2007) and plays an important ecological role in substrate cycling (Mermillod-Blondin \& Rosenberg 2006). It lives in J-shaped burrows in sandy beaches in the littoral zone, driving oxygenated surface water into the sediment by burrow ventilation. A. marina feeds at depth and deposits a faecal cast at the surface, thereby causing a vertical circulation of sand (Cadée 1976). There are ca. 40 min cycles of ingestion and egestion, and sediment throughput is between 4.7 and $80 \mathrm{~cm}^{3}$ worm ${ }^{-1}$ $\mathrm{d}^{-1}$ (Cadée 1976) according to worm size. Sand residence time in the gut compartments is therefore relatively short: foregut, 11 to $22 \mathrm{~min}$; midgut, 29 to 
$58 \mathrm{~min}$; and hind gut, 20 to $40 \mathrm{~min}$ (Chen \& Mayer 1999), suggesting that the gut is unlikely to act as a 'rumen' in which food is fermented. Marine sedimentary bacteria are mostly attached to sediment grains (Ellery \& Schleyer 1984), making them available to sand grazers (Velji \& Albright 1993), and lugworms are equipped for bacterial digestion, having gut diverticulae, the oesophageal glands, that release bacteriolytic agents into the foregut resulting in differential digestion of the bacteria associated with the ingested sediment (Plante \& Mayer 1994, Plante 2000). The bioturbation activities of the lugworm have been likened to 'gardening' (Hylleberg 1975), but the bacteria whose growth might be stimulated by the socalled 'gardening' process of lugworms are unknown.

The combined process of sand circulation and oxygenation of the sediment at depth and the lysis of bacteria in the gut (Plante et al. 1996, Andresen \& Kristensen 2002) causes changes in the lipid biomarker composition and bacterial community structure (as revealed using ribosomal intergenic spacer analysis) of inhabited sediments (Grossi et al. 2006). The faecal casts of A. marina are enriched in 14:0, i15:0, a15:0, 15:0, br17:0, 18:1n-7 and 18:1n-9, indicative of the presence of sulphate-reducing bacteria (Edlund et al. 1985) and sulphur-oxidising bacteria (Conway \& McDowell 1991). The presence of these same fatty acids in both wild-collected and mesocosm-cultured lugworm tissues is indicative of bacteriophagy (Olive et al. 2009).

The complexity and composition of bacterial communities in bioturbated sediments varies greatly (Reichardt 1988, Steward et al. 1996, Lucas et al. 2003, Matsui et al. 2004, Papaspyrou et al. 2006). A systems approach, using simpler laboratory environments, makes it possible to investigate the impact of a single introduced macrobenthic species on the associated bacterial community. Adopting this approach, the lugworm Arenicola marina L. was introduced as a bioturbator in mesocosms comprising plastic boxes with a sand substrate maintained under recirculation, into which spent brewer's yeast was introduced below the sand layer as the organic food source. The system was a small-scale adaptation of larger units in a commercial production system (Seabait Ltd, now Shoreline Polychaete Farms). The yeast was selected as an easily replicated food with a known fatty acid profile that was as suitable a food item as more complex materials such as fermented marine algal biomass and fish farm waste (Olive et al. 2003). Possible foods for natural populations of A. marina have been suggested to include: (1) diatoms and plant cells associated with the sand surface and made available through the downward movement of sand in the head shaft (Grossmann \& Reichardt 1991, Andresen \& Kristensen 2002); (2) organic material buried at depth and ingested with the sand substrate possibly after bacterial degradation (Kermace 1955, Retraubun et al. 1996); (3) meiofauna living in the region of the sand pocket (Hüttel 1990, Retraubun et al. 1996); and (4) bacteria associated with the ingested sand grains.

In order to characterise the diverse bacterial communities that developed within different compartments of the mesocosms, to reveal possible effects of the bioturbation, and to shed further light on the putative 'gardening' process, 16S rRNA gene clone libraries were constructed from sediment samples taken at 4 key points in the mesocosms.

\section{MATERIALS AND METHODS}

\section{System set-up}

The mesocosm systems comprised plastic boxes $(23 \times 37 \times 27 \mathrm{~cm})$ maintained in a recirculation system (see Olive et al. 2009 for further details). Beach sand from Cullercoats Bay, Northumberland, UK, was dried and sieved (mesh diameter $600 \mu \mathrm{m}$ ) before being added to cover the 'food' (brewers' yeast) until there was a yeast-sand combination layer about $4 \mathrm{~cm}$ high. Further clean sieved beach sand was added to a total height of $8 \mathrm{~cm}$. The boxes were then introduced to the recirculation aquarium system, and light was excluded using double thickness black plastic bags tightly fitting and sealed on the top of the boxes in order to eliminate photosynthetic algae as a food source for the worms. The system units were provided with recirculating artificial sea water (Tropical Marine Centre) at 17 to $18^{\circ} \mathrm{C}$, salinity at 32 to $33 \mathrm{ppt}$, $\mathrm{pH}$ at 8.0 to 8.3 and dissolved oxygen input of 7.5 to $8.5 \mathrm{mg} \mathrm{l}^{-1}$ (234.4 to $265.6 \mu \mathrm{mol} \mathrm{l}^{-1}$ ).

\section{Sample collection}

Sand samples from the chosen depth were taken with a wide bore plastic pipette $1 \mathrm{~cm}$ from the bottom of the box (deep yeast layer, DYL), $4 \mathrm{~cm}$ from the bottom of the box (mid sand, MS), and from new casts (NC), i.e. those produced within $24 \mathrm{~h}$, and old casts (OC) produced more than $24 \mathrm{~h}$ prior to sampling, and stored at $-80^{\circ} \mathrm{C}$. The bacterial community was analysed from pooled sediment samples from 3 replicate units taken 6 wk after initial stocking. 


\section{DNA extraction, 16S amplification and cloning}

Bacterial genomic DNA was obtained from samples using an SDS-based extraction (Zhou et al. 1996). Small DNA fractions were removed by running the genomic DNA through a chromatography column (BIO-RAD Micro Bio-Spin 6 column, Tris). Humic acid contamination was reduced by the addition of $100 \mu$ PVPP to the top of the column.

Universal bacterial primers $27 \mathrm{f}$ (5'-GAG TTT GAT CCT GGC TCA G-3') and 1525r (5'-AAG GAG GTG WTC CAR CC-3') were used to amplify the 16S rRNA genes in each sample with the following reaction mix: $100 \mathrm{ng}$ sediment DNA, $0.2 \mu \mathrm{M}$ of each primer, $0.2 \mathrm{mM}$ dNTP, $0.5 \mathrm{mg} \mathrm{ml}^{-1}$ non-acetylated BSA, $5 \mu \mathrm{l}$ $10 \times$ buffer (Biolab), $0.5 \mu$ Biolab standard Taq polymerase and Milli Q water to a final volume of $50 \mu \mathrm{l}$. The thermal cycling protocol was $95^{\circ} \mathrm{C}$ for $2 \mathrm{~min}$, 30 cycles of $95^{\circ} \mathrm{C}$ for $30 \mathrm{~s}, 55^{\circ} \mathrm{C}$ for $30 \mathrm{~s}, 72^{\circ} \mathrm{C}$ for $2 \mathrm{~min}$ and a final step at $72^{\circ} \mathrm{C}$ for $15 \mathrm{~min}$.

Amplified fragments were then ligated and transformed using the TOPO TA cloning kit (Invitrogen; chemical transformation protocol, pCR 2.1-topo vector and TOP10 Competent cells). Clone libraries of approximately 1000 white colonies per sample were obtained.

\section{Plasmid amplification and sequencing}

Plasmids were amplified using a modified protocol from the TempliPhi 100 Amplification Kit (Ashforth 2008). Sequencing was carried out using a BigDye ${ }^{\mathrm{TM}}$ v. 3.1 Terminator Cycle Sequencing Kit (PE Applied Biosystems), and sequences were determined using an ABI 3730 sequencer by the IRES Sequencing Service at Newcastle University (UK).

\section{Sequence analysis}

Sequence contigs were aligned in Sequencher ${ }^{\mathrm{TM}}$ (Gene Codes Corporation), and 31 chimeras were identified and removed from further analysis using MALLARD (Ashelford et al. 2006). The sequences were classified into phylogenetic groups using the RDP Classifier (Wang et al. 2007), and reference sequences and query matches were collected from the NCBI database (Altschul et al. 1997). These sequences were aligned in CLUSTAL_W2 through the EMBL-EBI website (Larkin et al. 2007). Alignments were then viewed and the vector sequence removed in CLUSTAL_X (version 1.83; Thompson et al. 1997). Neighbour-joining trees were created in TREECON (Van de Peer \& De Wachter 1994) using the Jukes \& Cantor (1969) model for nucleotide substitution. Bootstrap values for 1000 replications were calculated, and those branches with $50 \%$ or greater were labelled. Tables of sequence similarity were created using PHYDIT (Jeon et al. 2005), and clones with a sequence similarity of $\geq 98 \%$ were considered to be the same phylotype (or operational taxonomic unit, OTU) for the purposes of calculating diversity statistics.

The program PAST (Ryan et al. 1995) was used to calculate Simpson's index, the Shannon-Wiener index, Chao-1 and rarefaction. Coverage estimates were calculated as defined by Good (1953). Following Singleton et al. (2001), the computer programme LIBSHUFF (from 'library shuffling') was used as a statistical test for the null hypothesis that two $16 \mathrm{~S}$ rRNA gene libraries are samples of the same prokaryotic community. It uses a distance matrix to calculate the coverage of a library for values of evolutionary distance (D) ranging from 0.0 to 0.5 in increments of 0.01. An evolutionary distance of 0.0 represents identical sequences, and an evolutionary distance of 0.50 is close to the maximal distance encountered in rRNA sequences within a prokaryotic domain.

\section{Bioturbation studies}

Different layers in a mesocosm unit were marked using coloured sand grains (Blackwell), with blue sand added to the yeast-enriched deep sand layer to a height of $4 \mathrm{~cm}$, green sand added to a height of $11 \mathrm{~cm}$ and red sand added to a $1 \mathrm{~cm}$ layer at the surface. The box was introduced to the recirculation system, and the area of red sand disturbed by the input water was noted and avoided during subsequent sampling. After 2 d, 9 depurated lugworms between 1 and $3 \mathrm{~g}$ wet weight, previously grown in similar, uncoloured mesocosms, were introduced to the box to simulate a well-developed mesocosm. Samples of new casts were collected daily for $7 \mathrm{~d}$ and then every second day for a further $21 \mathrm{~d}$. Additionally, 3 replicated core samples were taken using a wide-bore Pasteur pipette on Day 16 and Day 29. Sand samples were examined after spreading in water on a plastic haemocytometer slide to separate individual sand grains, and the number of normal and variously coloured sand grains was determined for a minimum of 100 grains per sample. Each coloured sand grain represented a relative proportion of the initial mix 
$($ red $=0.44 ;$ blue $=0.15 ;$ green $=0.33)$. The representative number of grains of each colour in the cast samples was determined as: (absolute number of each coloured grain)/(relative proportion of that colour). The percentage representation of each was then calculated as (100/sum of all representative grain colours)/(representative grains). The percentage contribution of the variously coloured sand grains was normalised by arcsine transformation prior to statistical evaluation.

\section{RESULTS}

\section{Bioturbation and movement of sand layers and selective feeding}

The stratification of the coloured sand grains was clearly changed by the activities of the lugworms; blue sand added to the DYL was transported to the surface, and the red sand at the surface was transported to depth. By Day 29, the initial stratification was no longer evident, a more equal proportion of the differently coloured sand being found at all depths (see Fig. S1 in the supplement at www.intres.com/articles/suppl/m439p019_supp.pdf).

\section{Sequence analysis}

In total, 495 sequences were obtained and submitted to GenBank under accession numbers FJ716838 to FJ717331. Results for Shannon, Simpson, Chao-1 values (Chao 1987) and coverage estimates (Table 1) were comparable to similar studies (Torsvik et al. 1996, Bissett et al. 2006), and, along with the rarefaction curves (Fig. 1), showed the OC sample as being the most diverse and least covered. The rarefraction curves did not plateau for any of the samples, indicating that not all OTUs in the samples would have been analysed.

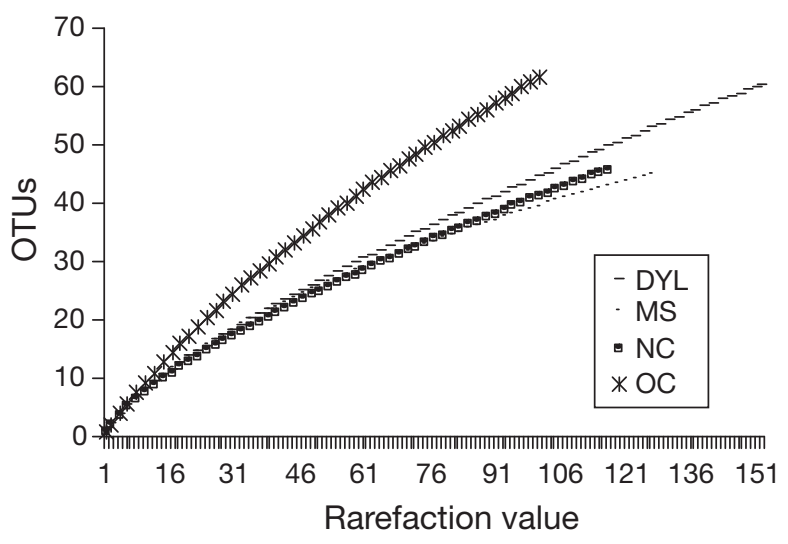

Fig. 1. Rarefaction curves of bacterial 16S rRNA gene sequences associated with sediment samples from deep yeast layer (DYL), mid sand (MS), new casts (NC) and old casts (OC) from an Arenicola marina growth mesocosm

\section{Phylogenetic analysis}

LIBSHUFF analysis was used on pairs of samples to determine the statistical similarity of those samples based on sequence comparison at all taxonomic levels. The libraries NC and OC were not significantly different $(p>0.05)$. The libraries DLY and MS were not significantly different $(\mathrm{p}>0.05)$. All other comparisons were significantly different $(p<0.05)$. The libraries therefore compartmentalised into 2 groups $(\mathrm{NC}+\mathrm{OC})$ and $(\mathrm{DYL}+\mathrm{MS})$ between which there were significant differences at a level below that of the major phylogenetic divisions (Fig. 2A,B).

The 495 clones representing 159 unique OTUs were sequenced and BLAST analysis carried out; sequence similarity ranged from 84.6 to $100 \%$ similarity to the closest match in the GenBank data base. Annotated phylogenetic trees for the major groups of bacterial clones that were sequenced are provided in Fig. S2 in the supplement, and the distribution of divisions between libraries is summarised in Table 2 .
Table 1. Clone library summary information of bacterial 16S rRNA gene sequences associated with sediment samples from the deep yeast layer (DYL), mid sand (MS), new casts (NC) and old casts (OC) from an Arenicola marina growth mesocosm. OTU: operational taxonomic unit

\begin{tabular}{|lcccccc|}
\hline Sample & OTUs & $\begin{array}{c}\text { Total } \\
\text { clones }\end{array}$ & $\begin{array}{c}\text { Shannon } \\
\text { index }\end{array}$ & $\begin{array}{c}\text { Simpson } \\
\text { index }\end{array}$ & $\begin{array}{c}\text { Coverage } \\
(\%)\end{array}$ & $\begin{array}{c}\text { Chao-1 } \\
\text { estimator }\end{array}$ \\
\hline DYL & 60 & 151 & 3.35 & 0.07 & 81.46 & $152.45 \pm 29.23$ \\
NC & 46 & 117 & 3.13 & 0.08 & 83.76 & $110.00 \pm 23.49$ \\
OC & 62 & 101 & 3.90 & 0.03 & 67.33 & $169.56 \pm 33.55$ \\
MS & 45 & 126 & 3.23 & 0.07 & 86.51 & $101.33 \pm 22.91$ \\
\hline
\end{tabular}

\section{Proteobacteria}

Within the 5 subdivisions of the Proteobacteria, 355 clones were assigned to 107 OTUs. Epsilonproteobacteria were most numerous in DYL and MS libraries ( $44 \%$ of total) and were present but less common in the NC and OC libraries, where they constituted approximately $20 \%$ in each case. The Epsilonproteobacteria OTUs were 

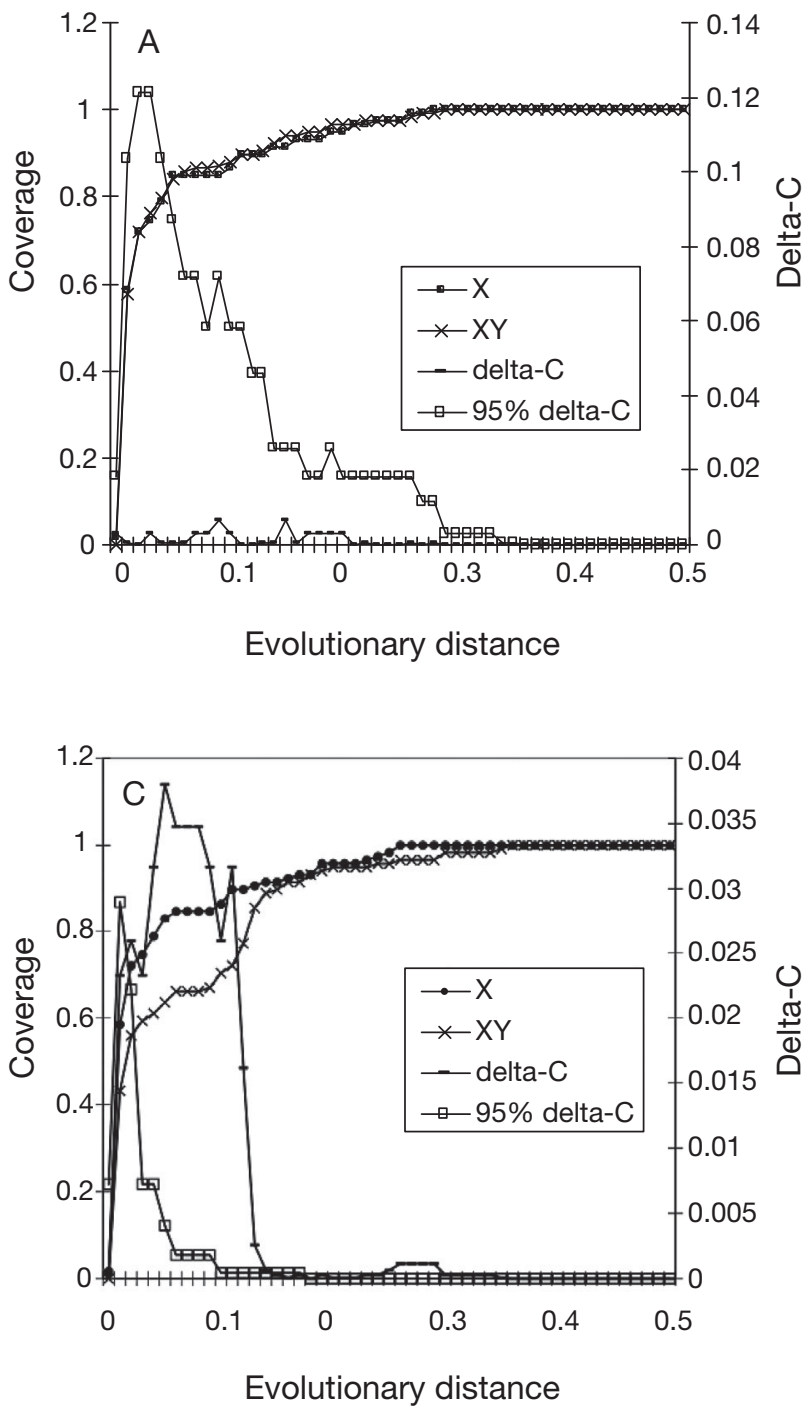

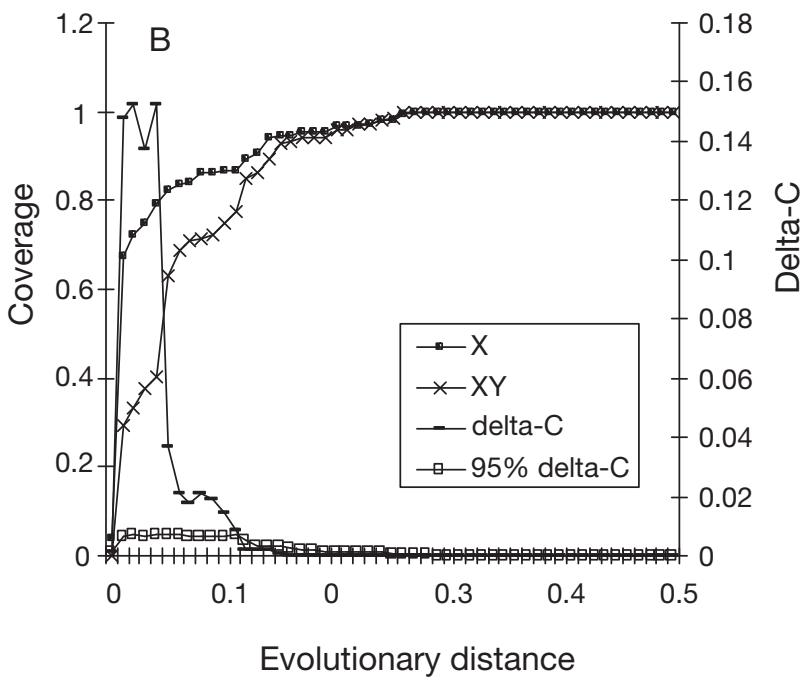

Fig. 2. LIBSHUFF coverage curve comparisons between clone libraries from the Arenicola marina bioturbated mesocosm. Dashes indicate delta-C values for samples at each value of evolutionary distance (D). D is equal to the Jukes-Cantor evolutionary distance determined by the DNADIST program of PHYLIP. Open squares indicate a p-value of 0.05 for $95 \%$ delta-C for the randomised samples. $\mathrm{X}$ is the homologous coverage curve and $\mathrm{XY}$ the heterologous coverage curve. $(\mathrm{A}, \mathrm{B})$ full library, (C) Epsilonproteobacteria in libraries. (A) $\mathrm{X}=$ new cast $(\mathrm{NC})$ library and $\mathrm{XY}=\mathrm{NC}$ library versus the old cast (OC) library. Comparison of libraries $\mathrm{NC}$ and OC shows that the actual values of delta-C do not exceed the comparable values at a probability value of 0.05 , indicating that $\mathrm{NC}$ and $\mathrm{OC}$ are not significantly different $(\mathrm{p}>0.05)$. (B) $\mathrm{X}=$ deep yeast layer (DYL) library and $\mathrm{XY}=\mathrm{DYL}$ library versus the NC library. The libraries DYL and NC are significantly different $(p<0.05)$. (C) $\mathrm{X}=\mathrm{DYL}+$ mid sand $(\mathrm{MS})$ combined Epsilonproteobacteria library and $\mathrm{XY}=\mathrm{NC}+\mathrm{OC}$ combined Epsilonproteobacteria library versus the DYL+mid sand (MS) combined Epsilonproteobacteria library. The libraries $\mathrm{NC}+\mathrm{OC}$ and $\mathrm{DYL}+\mathrm{MS}$ are significantly different $(p<0.05)$
Table 2. Bacterial 16S rRNA gene sequences associated with sediment samples from deep yeast layer (DYL), mid sand (MS), new casts (NC) and old casts (OC) from an Arenicola marina growth mesocosm, compared with sequences in the Genbank database (accessed July 2010)

\begin{tabular}{|c|c|c|c|c|c|}
\hline \multirow[t]{2}{*}{ Bacterial division } & \multicolumn{4}{|c|}{$\begin{array}{l}\text { Total no. clones } \\
\text { (no. phylotypes) }\end{array}$} & \multirow{2}{*}{$\begin{array}{l}\text { Sequence simi- } \\
\text { larity to closest } \\
\text { relative }(\%)\end{array}$} \\
\hline & DYL & $\mathrm{NC}$ & $\mathrm{OC}$ & MS & \\
\hline Epsilonproteobacteria & $67(10)$ & $26(6)$ & $21(8)$ & $60(13)$ & $87.4-99.8$ \\
\hline Gammaproteobacteria & $17(14)$ & $16(13)$ & $22(17)$ & $15(5)$ & $84.9-100$ \\
\hline Alphaproteobacteria & $12(10)$ & $16(8)$ & $20(13)$ & $15(10)$ & $85.5-99.8$ \\
\hline Verrucomicrobia & $20(1)$ & $25(2)$ & $10(3)$ & $8(2)$ & $94.2-98.9$ \\
\hline Deltaproteobacteria & $9(6)$ & $21(5)$ & $14(7)$ & $2(2)$ & $94.1-98.2$ \\
\hline CFB group & $17(10)$ & $10(9)$ & $7(7)$ & $17(5)$ & $89.8-98.0$ \\
\hline Others & $9(9)$ & $3(3)$ & $7(7)$ & $9(8)$ & $84.6-99.7$ \\
\hline
\end{tabular}

affiliated with cultured isolates and environmental clones commonly linked to sulphur oxidation and symbiosis with invertebrates, notably many from hydrothermal systems (Alain et al. 2002, Dubilier et al. 2008; see Fig. S2 for details). The phylotypes of Epsilonproteobacteria in the DYL and MS libraries differed significantly $(\mathrm{p}<$ 0.05 ) from those in the $\mathrm{NC}$ and $\mathrm{OC}$ libraries using LIBSHUFF (Figs. 2C and 3A). Epsilonproteobacteria phylotypes represented by the sequences FJ717071, FJ717008 and FJ717013 showed a $95 \%$ sequence similarity (Table 3) and strong evolutionary grouping (supported by high bootstrap values) with the cultured type strain Sulfurimonas denitrificans (Timmer-Ten Hoor 1975). These clones were numerous in the DYL and MS libraries yet completely absent in the NC and OC libraries (Fig. 3B). Con- 

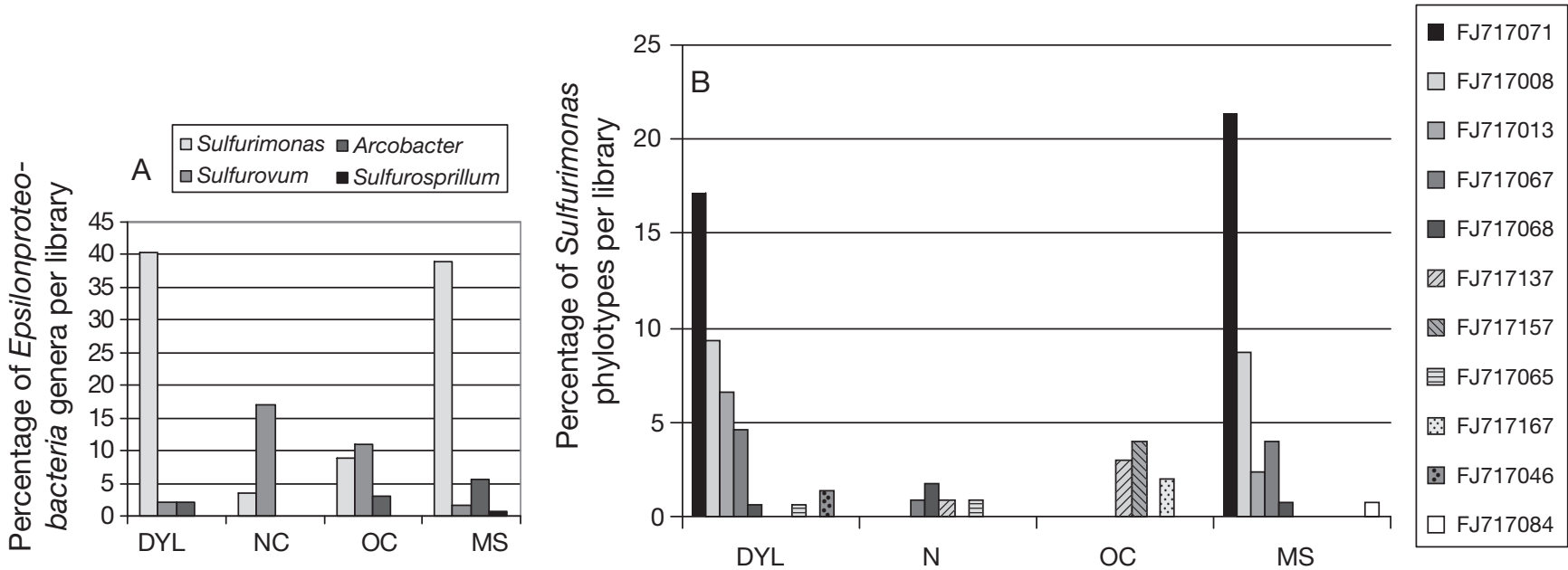

Fig. 3. (A) Percentage of Epsilonproteobacteria genera per library from the Arenicola marina bioturbated mesocosm; deep yeast layer (DYL), mid sand (MS), new casts (NC) and old casts (OC). (B) Percentage of Sulfurimonas phylotypes per library from the A. marina bioturbated mesocosm. Accession number of a representative clone from each phylotype is given. Phylotypes are calculated as sequences sharing $\geq 98 \%$ similarity

Table 3. Summary of Sulfurimonas phylotype 16S rRNA gene sequences identified in the clone libraries from the Arenicola marina bioturbated mesocosm compared with the 16S rRNA gene sequences of their closest cultured relatives

\begin{tabular}{|lcc|}
\hline $\begin{array}{l}\text { Closest cultured } \\
\text { organism }\end{array}$ & $\begin{array}{c}\text { Representative } \\
\text { phylotype } \\
\text { sequence }\end{array}$ & $\begin{array}{c}\text { Sequence } \\
\text { similarity } \\
(\%)\end{array}$ \\
\hline $\begin{array}{l}\text { S. denitrificans DSM 1251 } \\
\text { (CP000153) }\end{array}$ & $\begin{array}{c}\text { FJ717008 } \\
\text { FJ717046 }\end{array}$ & 94 \\
& FJ717071 & 95 \\
& FJ717031 & \\
& FJ717167 & \\
& FJ717084 & \\
S. autotrophica & FJ717065 & 96 \\
OK10 (NR_028643) & FJ717137 & 90 \\
& FJ717157 & 91 \\
& FJ717068 & 95 \\
& FJ717067 & 96 \\
\hline
\end{tabular}

versely, Sulfurimonas phylotypes represented by the sequences FJ717137 and FJ717157 which exhibit close sequence similarity to the hydrothermal aerobic species S. autotrophica (Inagaki et al. 2003; Table 3) and polychaete-associated anaerobicmicroaerobic $S$. paralvinella (Takai et al. 2006) were exclusively found in the $\mathrm{NC}$ and $\mathrm{OC}$ libraries (Fig. 3B). The other genera presented similar separation of phylotypes (not shown).

Among the Deltaproteobacteria, OTUs affiliated with Desulfobacter and Desulfovibrio clades were dominant in the NC and OC (and to a lesser extent DYL; Fig. S2). Sequences grouped with clones and cultured isolates from a variety of sources, e.g. deep sea water and sediment (Li et al. 1999, Madrid et al. 2001), estuarine biofilms (Moss et al. 2006) and organically enriched fish and shellfish aquaculture sediment (Asami et al. 2005, Bissett et al. 2006, Kawahara et al. 2008). Sulphur-reducing Deltaproteobacteria are common in marine sediment, especially that which is organically rich (Kawahara et al. 2008). Desulfobacter and Desulfovibrio have also been found in the burrows of the intertidal polychaete Diopatria cuprea (Matsui et al. 2004).

Most (>81\%) of the Alphaproteobacteria sequences were from the Rhodobacteriaceae and may have been transported by bioturbation, as they are not usually found at depth (Köpke et al. 2005). Alternatively they may have been introduced from the recirculation system, as Rhodobacteraceae have been found in biofilms of a closed recirculation system (Cytryn et al. 2005). The Gammaproteobacteria in the mesoscosm libraries showed a great diversity covering many genera (Table 2 and Fig. S2) and were most highly represented in the OC library. Only 2 Betaproteobacteria clones were found in this study, consistent with the observation that Betaproteobacteria are usually only found in small numbers in marine sediments (Asami et al. 2005, Moss et al. 2006).

\section{Verrucomicrobia}

Relatively large numbers of Verrucomicrobia occurred in the libraries (63 clones in total) and were 
most highly represented in the NC library (Table 2). The majority $(93 \%)$ were grouped into a single clade containing environmental clones from various marine sediments. Verrucomicrobia is a recently described phylum. It is known that some are involved in methane oxidation (Islam et al. 2008). Information about their role in the environment and the number of isolates recovered is slowly growing.

\section{Cytophaga-Flavobacteria-Bacteroides}

Representatives of the Cytophaga-FlavobacteriaBacteroides (CFB) group were also abundant and diverse (Table 2). CFB bacteria occur in many marine habitats, e.g. water column (Madrid et al. 2001), deep sea (Li et al. 1999), cold sediments (Bowman et al. 2003) and under shellfish farms (Asami et al. 2005). They have also been found in the mucous secretions of a hydrothermal polychaete (Alain et al. 2002). There were no representatives from the Chlorobi faction of the CFB group, commonly known as phototrophic green sulphur bacteria.

\section{Others}

The remaining phylogenetic groups comprised a diverse range of clones. OTUs fell into the Firmicutes, Planctomycetes, Nitrospira, Acidobacteria/ Fibrobacter, Actinobacteria, Chlorobacteria, Spirobacteria and WS3, each representing only a very small proportion of the libraries.

\section{DISCUSSION}

\section{Sulphur-cycle bacteria and the 'gardening' concept}

Virtually all of the clones found to differ in relative frequency between sites were among those most closely related to cultured species involved in the sulphur cycle. The distribution of these species may therefore be considered to be among those most influenced by the lugworm's bioturbatory activity. The behaviour of the worms, e.g. burrowing and casting, is essentially the same as in natural habitats (Cadée 1976, Rasmussen et al. 1998), and the system can be considered to mimic natural conditions. We therefore consider the possible influence of worm bioturbation on bacterial species and make a number of deductions about their possible role in the nutrition of the lugworm by annotating the key processes involved in the bioturbation cycle (see Cadée 1976) to reflect our findings:

(1) deep sediment, comprising the organically enriched layer (DYL) in our mesocosms, is raised to the surface;

(2) oxygen and carbon dioxide dissolved in the overlying sea water are driven into the sediment via the tail shaft by the peristaltic pumping activities of the worm;

(3) surface sand moves downwards in the head shaft; in our experiments, there was a virtually complete re-circulation and mixing of sand within $29 \mathrm{~d}$. In nature, such movement may also bring about an incorporation into the sediment of surface organic material and its downward transport to depth of feeding;

(4) the presence of iron sulphide is indicated at depth by black colouration, and black sand is cycled to the surface after egestion as indicated by the presence of black sand incorporating blue-grained sand in new casts in our experiments. There can still be sulphide present in sediment that is not black in colour;

(5) sulphate is likely to be created within the burrow system penetrating into the deep anaerobic sediment, and this is likely to be facilitated by the worm's pumping of oxygenated water into the burrows as well as sulphate that has been pumped into the burrow with the oxygenated water;

(6) detoxification of sulphide present in the pore water by the lugworm (see Vökel \& Grieshaber 1994) would also result in a flux of thiosulphate to the burrow pore water which in turn may be utilised by associated bacteria.

In its native environments, the lugworm Arenicola marina is known to be typically exposed to sulphidecontaining sediments, as indicated by black colouration of the sand surrounding the brown-coloured burrow linings; the sulphide concentration in the burrow pore water has been reported to be as high as $340 \mu \mathrm{mol} \mathrm{l} \mathrm{l}^{-1}$ (Vökel \& Grieshaber 1994). The lugworm is adapted to deal with anaerobic sulphidic environments, in which sulphur-oxidising bacteria are likely to thrive; sulphide detoxification takes place in body wall mitochondria, using either a branched respiratory chain or redox regulation of sulphide oxidation giving rise to thiosulphate (Hildebrandt \& Grieshaber 2008), which may leach into burrow pore water.

Linking specific groups of organisms to their use of particular substrates in the environment is an important step in understanding the link between microbial community structure and function (Miskin et al. 2001). Although such linkages are tentative, the exis- 
tence of functional data makes it possible to tentatively consider possible interactions between the lugworm and bacteria involved in the sulphur cycle using published biochemical and genomic data for the closest species. The main substrates utilised by the Epsilonproteobacteria are sulphide and thiosulphate, and these substrates may act as electron donors, whereas nitrate and oxygen act as electron acceptors (producing nitrogen gas). Additionally, we note that some Epsilonproteobacteria are autotrophic. Sievert et al. (2008) revealed the presence, in Sulfurimonas denitrificans, of genes encoding for the reductive citric acid cycle, which is consistent with prior indications of carbon fixation by Epsilonproteobacteria (Hügler et al. 2005).

There are only 3 cultured representatives of Sulfurovum, and only 17 clones have been identified from environmental studies, most of these having been found in samples collected from hydrothermal vent systems. However, our interpretations are aided by the recent publication of the complete genome sequences of a Sufurovum strain from deep-sea hydrothermal vents (Nakagawa et al. 2007) and of Sulfurimonas denitrificans from shallow-water marine sediments (Sievert et al. 2008).

Based on the phylogenetic and statistical analysis of the mesocosm libraries (see Table 3, Figs. 3 \& S2 in the supplement at www.int-res.com/articles/suppl/ m439p019_supp.pdf), we suggest the following scenario (represented diagrammatically in Fig. S3):

(1) firstly, yeast in the DYL may fuel the growth of fatty acid-utilising Deltaproteobacteria (Desulfovibrio acrylicus-like and Desulfobacter hydrogenophiluslike species) which initiate the conversion of the fermented products to acetate or carbon dioxide, sulphate to sulphide, and which produce and utilise hydrogen;

(2) Sulfurimonas denitrificans-like organisms abundant in DYL are then likely to convert the sulphide to sulphate, as well as reducing nitrate and nitrite to nitrogen and potentially utilising the carbon dioxide;

(3) the bioturbatory actions of the worm may facilitate the growth of the $S$. denitrificans-like species by enhancing substrate availability, e.g. by increasing the surface area exposed to oxygen, carbon dioxide, nitrate and nitrite;

(4) the worm ingests the bacteria-rich sand of the DYL, and during the passage of the sand through the gut it digests certain bacteria; comparisons of 16sRNA gene clone frequency suggest that digestion of the apparently abundant $S$. denitrificans occurs prior to deposition of the digested sediment at the surface;
(5) the deposited sand (NC) is likely to contain sulphide, ammonium and possibly undigested fatty acids and metabolic products from the worm itself, e.g. glycine and succinate;

(6) the sulphide in NC sand may then be converted to sulphate by Sulfurovum-like species and Sulfurimonas autrotrophica/paralvinella-like species, and ammonium in the sediment utilised as a growth source; also the oxygenation of sulphide can also occur quite fast abiotically when oxygen is present;

(7) nitrate, oxygen and carbon dioxide would be likely to diffuse in from the seawater surrounding the cast. Desulfovibrio acrylicus-like species and Desulfobacter hydrogenophilus-like species in a complementary process would tend to reduce the sulphate to sulphide and utilise the fatty acids and products from digestion to create and consume hydrogen;

(8) Desulfobacter hydrogenophilus-like species are also present and may utilise nitrogen produced by the Epsilonproteobacteria reduction of nitrate, and oxidise carbon dioxide from the water.

\section{Enhancement of mixing zones in the bioturbated sediment and facilitation of electron transfer}

The Epsilonproteobacteria and all Deltaproteobacteria in these sediments belong to taxa that grow under anaerobic or microaerobic conditions. In nonbioturbated sediments, the oxic zone is limited to the upper 1 to $5 \mathrm{~mm}$ (Ziebis et al. 1996, Zorn et al. 2006). However, the situation is different in a bioturbated system. The burrowing activity of Arenicola marina enhances the total oxygen flux diffusing into the substrate because of 3 processes: (1) the burrows increase the surface area of sediment in contact with oxygenated water with the formation of the burrows themselves, (2) the production of casts at the surface (Zorn et al. 2006) and (3) the peristaltic pumping activities of the worms which drives water headwards into the burrow system from the tail shaft to meet the respiratory requirements of the worms in this environment. While these processes increase the overall sediment surface exposed to oxygen, the penetration of oxygen through the $A$. marina burrow walls into the surrounding sediment is only to a distance of about $0.95 \mathrm{~mm}$ which is similar to that across the surface of unburrowed sediment (Zorn et al. 2006). Anaerobic conditions would therefore have been maintained in the bulk of the sediment in the DYL and MS sites as indicated by the black colour (Fig. S4). The distribution of the microaerobic Sulfurovum- and anaerobic Desulfovibrio- and Desul- 
fobacter-like groups suggest that anoxic conditions also occurred to some extent in the NC and OC sediments, as also indicated by the presence of black sand (Fig. S4), again due to low penetration of oxygen as mentioned above, inhibited further by a thin layer of mucus from the worm (Zorn et al. 2006). A. marina defecates approximately every $45 \mathrm{~min}_{\text {; there- }}$ fore, another mound of anoxic sediment will be deposited on top of the previous cast, again obstructing the penetration of oxygen. The actions of the worm (burrowing, irrigation and sand recirculation) and cast deposition thus could create at least 2 sites for enhanced sulphur and carbon cycling by increasing the areas of redox potential, one at depth and one at the surface. The close association of sulphurcycling bacteria with each other and their syntrophy with other microbes, as well as their strategies to utilise substrates that may be in limited or at toxic levels, has been documented in a variety of environments (Cord-Ruwisch et al. 1988, Overmann \& van Gemerden 2000). Sulfurimonas denitrificans is reported to be oxygen-sensitive, and the genome contains an array of $\mathrm{O}_{2}$ protection sequences; however, a cluster of 4 genes which encode the FixNOQP proteins indicate that this species may also have an ability to use oxygen as a terminal electron acceptor (Sievert et al. 2008). The ecology and microdistribution of these species in organically enriched anaerobic sediments punctuated by oxic islands emanating from the burrow system of a bioturbator such as A. marina is potentially complex and should be investigated further. Recent observations on the Sox (sulphur oxidising) enzyme system in Sufurovum strain NBC37-1 revealed that while the Sox enzyme system was constitutively expressed, the expression of sulphur-reduction enzymes varied depending on the culture conditions, hence a change in energy metabolism in response to the variable physical and chemical conditions in mixing zones between hydrothermal fluid and ambient seawater (Yamamoto et al. 2010).

In terms of worm growth and lipid composition, the mesocosm units mimic at a small scale the larger commercial systems (e.g. Shoreline Polychaete Farms) and provide insights into conditions that may sometimes occur in natural environments that have a high organic loading. The introduction of an enriched organic layer which is detected and utilised by the worms promotes rapid growth (Olive et al. 2003). Conditions occurring in natural environments are more variable, but lugworms are frequently found in conditions where there is high organic content at depth, e.g. through the burial of algal material. The finding that clones of sulphur oxidising-related Epsilonproteobacteria were particularly common in these samples is particularly interesting, since in many marine habitats it is the Gammaproteobacteria that have been found to complement Deltaproteobacteria in sulphur-cycling processes (Overmann \& van Gemerden 2000, Kawahara et al. 2008). Goni Urriza et al. (1999) found that populations of colourless sulphur-oxidising bacteria were higher in natural bioturbated sites (containing Arenicola marina) than at control sites and that both samples became additionally enriched with colourless sulphur-oxidising bacteria under laboratory conditions. Unfortunately, they did not identify which taxa of colourless sulphur-oxidising bacteria were involved.

Although metabolic characteristics cannot always be assumed from phylogeny, and 16SrRNA gene clone frequency is not an absolute measure of organism frequency, our data do suggest that previously unreported processes may occur in bioturbated shallow-water marine sediments with a high organic content. A cautious inference from the libraries obtained from the microcosms is that sulphur-oxidising bacteria initially isolated from hydrothermal vent systems (Dubilier et al. 2008) may play a significant role in sulphur cycling in these systems, and it is possible that similar processes sometimes occur in natural shallow-water sediments. Measurements of pore water constituents and chemical fluxes in such systems should therefore be carried out, and the nature of the bacterial communities ascertained. We draw together circumstantial evidence that these processes could be facilitated by the bioturbation activities of the lugworm. If, as our observations suggest, the activities of the lugworm enhance the growth of some species of bacteria, which are subsequently digested, this would be entirely consistent with the concept of bacterial gardening by lugworms. Bioturbation in marine sediments is of global significance (see Teal et al. 2008), and further analysis of the possible role of the groups of bacteria found in these studies should be carried out in order to gain further understanding of sulphur cycling within natural bioturbated organically rich sediments. The relative importance of chemoautolithotrophic processes in shallow-water marine sediments subject to invertebrate-driven bioturbation may have been significantly underestimated.

Acknowledgements. This work would not have been possible without the funding from the Natural Environment Research Council (NERC) and Newcastle University and the support of Shoreline Polychaete Farms. 


\section{LITERATURE CITED}

Alain $K$, Olagnon $M$, Desbruyères $D$, Pagé $A$ and others (2002) Phylogenetic characterization of the bacterial assemblage associated with mucous secretions of the hydrothermal vent polychaete Paralvinella palmiformis. FEMS Microbiol Ecol 42:463-476

Aller RC (2001) Transport and reactions in the bioirrigated zone. In: Boudreau BP, Jørgensen BB (eds) The benthic boundary layer: transport processes and biogeochemistry. Oxford University Press, New York, NY, p 269-301

Alongi DM (1985) Microbes, meiofauna and bacterial productivity on tubes constructed by the polychaete Capitella capitata. Mar Ecol Prog Ser 23:207-208

> Altschul SF, Madden TL, Schaffer AA, Zhang J, Zhang Z, Miller W, Lipman DJ (1997) Gapped BLAST and PSIBLAST: a new generation of protein database search programs. Nucleic Acids Res 25:3389-3402

Andresen M, Kristensen E (2002) The importance of bacteria and microalgae in the diet of the deposit-feeding polychaete Arenicola marina. Ophelia 56:179-196

> Asami H, Aida M, Watanabe K (2005) Accelerated sulfur cycle in coastal marine sediment beneath areas of intensive shellfish aquaculture. Appl Environ Microbiol 71: 2925-2933

Ashelford KE, Chuzhanova NA, Fry JC, Jones AJ, Weightman AJ (2006) New screening software shows most recent large 16S rRNA gene clone libraries contain chimeras. Appl Environ Microbiol 72:5734-5741

Ashforth E (2008) Bacterial diversity in an Arenicola marina bioturbated mesocosm. PhD thesis, Newcastle University

$>$ Bissett A, Bowman J, Burke C (2006) Bacterial diversity in organically-enriched fish farm sediments. FEMS Microbiol Ecol 55:48-56

Bowman JP, McCammon SA, Gibson JAE, Robertson L, Nichols PD (2003) Prokaryotic metabolic activity and community structure in Antarctic continental shelf sediments. Appl Environ Microbiol 69:2448-2462

Cadée GC (1976) Sediment reworking by Arenicola marina on tidal flats in the Dutch Wadden Sea. Neth J Sea Res 10:440-460

Chao A (1987) Estimating the population size for capturerecapture data with unequal catchability. Biometrics 43: 783-791

> Chen Z, Mayer LM (1999) Sedimentary metal bioavailability determined by the digestive constraints of marine deposit feeders: gut retention time and dissolved amino acids. Mar Ecol Prog Ser 176:139-151

Conway N, McDowell CJ (1991) Incorporation and utilization of bacterial lipids in the Solemya velum symbiosis. Mar Biol 108:277-291

> Cord-Ruwisch R, Seitz HJ, Conrad R (1988) The capacity of hydrogenotrophic anaerobic bacteria to compete for traces of hydrogen depends on the redox potential of the terminal electron acceptor. Arch Microbiol 149:350-357

> Cytryn E, Minz D, Gelfand I, Neori A, Gieseke A, de Beer D, van Rijn J (2005) Sulfide-oxidizing activity and bacterial community structure in a fluidized bed reactor from a zero-discharge mariculture system. Environ Sci Technol 39:1802-1810

> Dubilier N, Bergin C, Lott C (2008) Symbiotic diversity in marine animals: the art of harnessing chemosynthesis. Nat Rev Microbiol 6:725-740

- Edlund A, Nichols PD, Roffey R, White DC (1985) Extractable and lipopolysaccharide fatty acid and hydroxy acid profiles from Desulfovibrio species. J Lipid Res 26:982-988

Ellery WN, Schleyer MH (1984) Comparison of homogenization and ultrasonication as techniques in extracting attached sedimentary bacteria. Mar Ecol Prog Ser 15: $247-250$

Gérino M, Stora G, François-Carcaillet F, Gilbert F and others (2004) Macro-invertebrate functional groups in freshwater and marine sediments: a common mechanistic classification. Vie Milieu 53:221-232

Goni-Urriza M, de Montaudouin X, Guyoneaud R, Bachelet G, de Wit R (1999) Effect of macrofaunal bioturbation on bacterial distribution in marine sandy sediments, with special reference to sulphur-oxidising bacteria. J Sea Res 41:269-279

Good IJ (1953) The population frequencies of species and the estimation of population parameters. Biometrika 40: $237-264$

Grossi V, Cuny P, Caradec S, Nerini D, Pancost R, Gilbert F (2006) Impact of feeding by Arenicola marina (L.) and ageing of faecal material on fatty acid distribution and bacterial community structure in marine sediments: an experimental approach. J Exp Mar Biol Ecol 336:54-64

Grossmann S, Reichardt W (1991) Impact of Arenicola marina on bacteria in intertidal sediments. Mar Ecol Prog Ser 77:85-93

Hildebrandt TM, Grieshaber MK (2008) Redox regulation of mitochondrial sulfide oxidation in the lugworm, Arenicola marina. J Exp Biol 211:2617-2623

Hügler M, Wirsen CO, Fuchs G, Taylor CD, Sievert SM (2005) Evidence for autotrophic $\mathrm{CO}_{2}$ fixation via the reductive tricarboxylic acid cycle by members of the subdivision of Epsilonproteobacteria. J Bacteriol 187: 3020-3027

Hüttel M (1990) Influence of the lugworm Arenicola marina on porewater nutrient profiles of sand flat sediments. Mar Ecol Prog Ser 62:241-248

Hylleberg J (1975) Selective feeding by Abarenicola pacifica with notes on Abarenicola vagabunda and the concept of gardening in lugworms. Ophelia 14:113-137

Inagaki F, Takai K, Kobayashi H, Nealson KH, Horikoshi K (2003) Sulfurimonas autotrophica gen. nov., sp. nov., a novel sulfur-oxidizing $\varepsilon$-proteobacterium isolated from hydrothermal sediments in the Mid-Okinawa Trough. Int J Syst Evol Microbiol 53:1801-1805

Islam $\mathrm{T}$, Jensen $\mathrm{S}$, Reigstad LJ, Larsen $\varnothing$, Birkeland NK (2008) Methane oxidation at $55^{\circ} \mathrm{C}$ and $\mathrm{pH} 2$ by a thermoacidophilic bacterium belonging to the Verrucomicrobia phylum. Proc Natl Acad Sci USA 105:300-304

Jeon YS, Chung H, Park S, Hur I, Lee JH, Chun J (2005) jPHYDIT: a JAVA-based integrated environment for molecular phylogeny of ribosomal RNA sequences. Bioinformatics 12:3171-3173

Jukes TH, Cantor CR (1969) Evolution of protein molecules. Academic Press, New York, NY

Kawahara N, Shigematsu K, Miura S, Miyadai T, Kondo R (2008) Distribution of sulfate-reducing bacteria in fish farm sediments on the coast of southern Fukui Prefecture, Japan. Plankton Benthos Res 3:42-45

Kermace DM (1955) The anatomy and physiology of the gut of the polychaete Arenicola marina (L.). Proc Zool Soc Lond 125:347-381

Köpke B, Wilms R, Engelen B, Cypionka H, Sass H (2005) Microbial diversity in coastal subsurface sediments: a cultivation approach using various electron acceptors 
and substrate gradients. Appl Environ Microbiol 71: 7819-7830

Larkin MA, Blackshields G, Brown NP, Chenna R and others (2007) ClustalW and ClustalX version 2. Bioinformatics 23:2947-2948

Li L, Kato C, Horikoshi K (1999) Microbial diversity in sediments collected from the deepest cold-seep area, the Japan Trench. Mar Biotechnol 1:391-400

Lucas FS, Bertru G, Hofle MG (2003) Characterization of free-living and attached bacteria in sediments colonized by Hediste diversicolor. Aquat Microb Ecol 32:165-174

- Madrid VM, Taylor GT, Scranton MI, Chistoserdov AY (2001) Phylogenetic diversity of bacterial and archaeal communities in the anoxic zone of the Cariaco Basin. Appl Environ Microbiol 67:1663-1674

Matsui GY, Ringelberg DB, Lovell CR (2004) Sulfatereducing bacteria in tubes constructed by the marine infaunal polychaete Diopatra cuprea. Appl Environ Microbiol 70:7053-7065

> Mermillod-Blondin F, Rosenberg R (2006) Ecosystem engineering: the impact of bioturbation on biogeochemical processes in marine and freshwater benthic habitats. Aquat Sci 68:434-442

Miskin IP, Raymne D, Head IM, Curtis TP (2001) Is community assembly random or deterministic? ISME 9, Amsterdam

> Moss JA, Nocker A, Lepo JE, Snyder RA (2006) Stability and change in estuarine biofilm bacterial community diversity. Appl Environ Microbiol 72:5679-5688

Nakagawa S, Yakaki S, Shimamura A, Reysenbach K, Takai K, Horikoshi K (2007) Deep-sea vent Epsilonproteobacteria genomes provide insights into the emergence of pathogens. Proc Natl Acad Sci USA 104:12146-12150

Olive PJW, Craig S, Cowin PBD (2003) The aquaculture of marine worms (lugworms). Patent WO/2003/007701, International Application No.:PCT/GB2002/003021Publication Date: 30.01.2003, International Filing Date: 01.07 .2002

Olive PJW, Duangchinda T, Ashforth E, Craig S, Ward AC, Davies SJ (2009) Net gain of long-chain polyunsaturated fatty acids (PUFA) in a lugworm (Arenicola marina L) bioturbated mesocosm. Mar Ecol Prog Ser 387:223-239

> Overmann J, van Gemerden H (2000) Microbial interactions involving sulfur bacteria: implications for the ecology and evolution of bacterial communities. FEMS Microbiol Rev 24:591-599

Papaspyrou S, Gregersen T, Kristensen E, Christensen B, Cox RP (2006) Microbial reaction rates and bacterial communities in sediment surrounding burrows of two nereidid polychaetes (Nereis diversicolor and $N$. virens). Mar Biol 148:541-550

Phillips TM, Lovell CR (1999) Distributions of total and active bacteria in biofilms lining tubes of the onuphid polychaete Diopatra cuprea. Mar Ecol Prog Ser 183: 169-178

> Plante CJ (2000) Role of bacterial exopolymeric capsules in protection from deposit-feeder digestion. Aquat Microb Ecol 21:211-219

Plante CJ, Mayer LM (1994) Distribution and efficiency of bacteriolysis in the gut of Arenicola marina and three additional deposit feeders. Mar Ecol Prog Ser 109: 183-194

Plante CJ, Mayer LM, King GM (1996) The kinetics of bacteriolysis in the gut of the deposit feeder Arenicola marina. Appl Environ Microbiol 62:1051-1057
Rasmussen AD, Banta GT, Andersen O (1998) Effects of bioturbation by the lugworm Arenicola marina on cadmium uptake and distribution in sandy sediments. Mar Ecol Prog Ser 164:179-188

> Reichardt W (1988) Impact of bioturbation by Arenicola marina on microbiological parameters in intertidal sediments. Mar Ecol Prog Ser 44:149-158

- Retraubun ASW, Dawson M, Evans SM (1996) The role of the burrow funnel in feeding processes in the lugworm Arenicola marina (L.). J Exp Mar Biol Ecol 202: 107-118

Ryan PD, Harper DAT, Whalley JS (1995) PALSTAT, Statistics for palaeontologists. Chapman \& Hall, London

Sievert SM, Scott KM, Klotz MG, Chain PSG and others (2008) Genome of the Epsilonproteobacterial chemolithoautotroph Sulfurimonas denitrificans. Appl Environ Microbiol 74:1145-1156

Singleton DR, Furlong MA, Rathbun SL, Whitman WB (2001) Quantitative comparisons of $16 \mathrm{~S}$ rDNA sequence libraries from environmental samples. Appl Environ Microbiol 67:4373-4376

> Steward CC, Nold SC, Ringelberg DB, White DC, Lovell CR (1996) Microbial biomass and community structures in the burrow of bromophenol producing and non-producing marine worms and surrounding sediments. Mar Ecol Prog Ser 133:149-165

Takai K, Suzuki M, Nakagawa S, Miyazaki M, Suzuki Y, Inagaki F, Horikoshi K (2006) Sulfurimonas paralvinellae sp. nov., a novel mesophilic, hydrogen- and sulfuroxidizing chemolithoautotroph within the Epsilonproteobacteria isolated from a deep-sea hydrothermal vent polychaete nest, reclassification of Thiomicrospira denitrificans as Sulfurimonas denitrificans comb. nov. and emended description of the genus Sulfurimonas. Int J Syst Evol Microbiol 56:1725-1733

Teal LR, Bulling MT, Parker ER, Solan M (2008) Global patterns of bioturbation intensity and mixed depth of marine soft sediments. Aquat Biol 2:207-218

Thompson JD, Gibson T, Plewniak F, Jeanmougin F, Higgins D (1997) The CLUSTAL_X windows interface: flexible strategies for multiple sequence alignment aided by quality analysis tools. Nucleic Acids Res 25:4876-4882

- Timmer-Ten Hoor A (1975) A new type of thiosulphate oxidizing, nitrate reducing microorganism: Thiomicrospira dentrificans sp. nov. Neth J Sea Res 9:344-350

> Torsvik V, Sørheim R, Goksøyr J (1996) Total bacterial diversity in soil and sediment communities - a review. J Ind Microbiol Biotechnol 17:170-178

Van de Peer Y, De Wachter R (1994) TREECON for Windows: a software package for the construction and drawing of evolutionary trees for the Microsoft Windows environment. Comput Appl Biosci 10:569-570

Velji MI, Albright LJ (1993) Improved sample preparation for enumeration of aggregated aquatic substrate bacteria. In: Kemp PF, Cole JJ (eds) Handbook of methods in aquatic microbial ecology. Lewis Publishers, Boca Raton, FL, p 139-142

> Vökel S, Grieshaber MK (1994) Oxygen dependent sulfide detoxification in the lugworm Arenicola marina. Mar Biol 118:137-147

> Volkenborn N, Hedtkamp SIC, van Beusekom JEE, Reise K (2007) Effects of bioturbation and bioirrigation by lugworms (Arenicola marina) on physical and chemical sediment properties and implications for intertidal habitat succession. Estuar Coast Shelf Sci 74:331-343 
Wang Q, Garrity GM, Tiedje JM, Cole JR (2007) Naïve Bayesian classifier for rapid assignment of rRNA sequences into the new bacterial taxonomy. Appl Environ Microbiol 73:5261-5267

Yamamoto M, Nakagawa S, Shimamura S, Takai $K_{\text {, }}$ Horikoshi K (2010) Molecular characterization of inorganic sulfur-compound metabolism in the deep-sea Epsilonproteobacterium Sulfurovum sp. NBC37-1. Environ Microbiol 12:1144-1153

Editorial responsibility: Peter Steinberg,

Sydney, New South Wales, Australia
Zhou J, Bruns MA, Tiedje JM (1996) DNA recovery from soils of diverse composition. Appl Environ Microbiol 62: 316-322

> Ziebis W, Huettel M, Forster S (1996) Impact of biogenic sediment topography on oxygen fluxes in permeable seabeds. Mar Ecol Prog Ser 140:227-237

Zorn ME, Lalonde SV, Gingras MK, Pemberton SG, Konhauser KO (2006) Microscale oxygen distribution in various invertebrate burrow walls. Geobiology 4:137-145

Submitted: September 13, 2010; Accepted: July 21, 2011 Proofs received from author(s): October 7, 2011 